Киченко О. С.

Доктор філологічних наук, професор кафедри російської мови, зарубіжної літератури та методики навчання

Черкаського національного університету імені Богдана Хмельницького

\title{
РЕЦЕНЗІЯ НА МОНОГРАФІЮ С. А. КОМАРОВА «ЖАНР ФЕЛЬЕТОНА В РУССКОЙ СОВЕТСКОЙ ЛИТЕРАТУРЕ 1920-Х - НАЧАЛА 1930-Х ГОДОВ» (МАРИУПОЛЬ, 2015)
}

У сучасному літературознавстві широко дискутується проблема жанру. Що формує жанр? Як відбувається процес жанроутворення? Яку роль у цьому відіграють форма та зміст твору, епоха, напрямок, читацька рецепція? Ці та інші питання постають у багатьох роботах - не тільки теоретиків, але й істориків літератури. Рецензована монографія С. А. Комарова, присвячена жанру фейлетона, відображає дану наукову тенденцію. У роботі пропонується розгляд своєрідності фейлетону у творчості письменників, які зробили вагомий внесок у розвиток жанру: М. Булгакова, М. Зощенка, В. Катаєва, М. Кольцова, I. Ільфа та Є. Петрова. Зосередившись на дослідженні фейлетонних доробків радянських митців, автор книги порушує й питання історії жанру в російській літературі XIX - початку XX століття.

Монографія має традиційну структуру і складається зі вступу, трьох розділів та висновків. У першому розділі висвітлюються питання теорії фейлетонного жанру, ступінь їх розробки у радянській та сучасній науці; через характеристику сутності публіцистики та художньої літератури, жанрів, які корелюються із фейлетоном (нарис, оповідання), та різних видів комічного (гумор, сатира, іронія, сарказм) виявляються їх ознаки у фейлетоні. Автор наводить різні думки щодо жанрової природи фейлетону (особливо суперечливими вони були у 1920-ті роки - період активної розробки теорії та практики жанру), знаходить точки зіткнення літератури та публіцистики - це потрібно для більш ілюстративної презентації синкретичної сутності фейлетону. Прагнучи скласти якомога цілісне уявлення про категорію комічного та його форми, С. А. Комаров чомусь обходить увагою явище 
гротеску - це тим більш дивно, що у ході аналізу фейлетонних текстів (у другому і третьому розділах) неодноразово акцентуються його вияви.

Інтерес викликає другий розділ монографії, у якому окреслюється історія жанру в російській літературі XIX - початку XX століття. Автор вибудовує матеріал згідно хронологічного принципу. Виокремлюючи три етапи розвитку жанру (1820-30-ті, 1840-80-ті, межа століть), науковець зупиняється на вивченні фейлетонів письменників вказаного періоду (зокрема, К. Ф. Рилєєва, Ф. В. Булгаріна, О. І. Сенковського, О. І. Герцена, Ф. М. Достоєвського, М. О. Некрасова, М. С. Салтикова-Щедріна, А. П. Чехова, В. М. Дорошевича, А. Т. Аверченко, Н. О. Теффі та ін.). Така пильна увага до питання історії фейлетону цілком виправдана, адже цей огляд дозволяє показати процес формування жанру, який, у підсумку, призвів до його розквіту вже у нову соціально-політичну та культурну епоху - 1920-ті роки.

Основна частина роботи зосереджена на дослідженні безпосередньо фейлетоністики 1920-х - початку 1930-х років. С. А. Комаров пропонує системний аналіз спадщини найбільш визначних фейлетоністів доби: М. А. Булгакова, М. М. Зощенка, В. П. Катаєва, М. Ю. Кольцова, І. А. Ільфа, Є. П. Петрова. В дослідницькій орбіті постійно знаходяться як змістовні, так і формальні аспекти фейлетонного методу кожного 3 письменників. Виходячи 3 індивідуальних особливостей розкриття загалом однорідної проблематики, автор монографії типологізує фейлетони: говорить про художній фейлетон М. Булгакова, публіцистичний фейлетон М. Кольцова, домінування у творчості М. Зощенка, В. Катаєва, І. А. Ільфа, С. П. Петрова теж «художнього» типу. Підставою для класифікації стає, також, форма комічного (відповідно постулюється наявність сатиричного та гумористичного фейлетону), об'єкт зображення (зокрема, йде мова про «зовнішньополітичний» фейлетон М. Кольцова та В. Катаєва, «літературний» фейлетон А. Бухова, В. Катаєва, I. Ільфа. С. Петрова, «професійний» та «ретро-фейлетон» М. Зощенка та ін.).

Грунтовністю відзначається дослідження проблемного шару фейлетоністики різних за творчими манерами митців. Натомість, не так 
докладно висвітлюються особливості поетики: звертається увага, перш за все, на структурно-композиційну своєрідність, форми стилізації, інтертекстуальність та розвиток традицій жанру (наприклад, М. С. СалтиковаЩедріна, В. М. Дорошевича, сатириконців) у фейлетоні 1920-х - початку 1930-х років. У монографії виявлені характерні риси, властиві авторському почерку того чи іншого фейлетоніста.

Такий характер вивчення корпусу фейлетонних текстів зазначеного періоду дозволив осмислити і окреслити подальшу перспективу звернення до інших жанрових форм: віршованого фейлетону, фейлетонної повісті, романуфейлетону. Пропонована С. А. Комаровим концепція, сутність якої полягає у думці про поступовість розвитку фейлетону в російській літературі та закономірність його розквіту в післяреволюційну добу, ще потребує подальшої конкретизації, що може скласти перспективу розробки проблеми. Очевидно, що монографія заповнює певну прогалину у вивченні сатирико-гумористичної літератури та допомагає краще зрозуміти таке неоднозначне явище, як фейлетон. 